\title{
Unity and Disunity in the Positive Tradition
}

\author{
Michael Garnett
}

Positive freedom can be hard to pin down. While negative freedom may be characterized as an absence of coercion or physical prevention, and republican freedom as an absence of interpersonal domination, positive freedom resists such pithy treatment. Moreover, this isn't due to a lack of possible elucidations but due to an overabundance of them. The term is widely taken to refer to a variety of seemingly distinct goods, including but not limited to actually exercisable options or capabilities (Crocker I980; Gould I988); collective self-determination (Taylor I979: I75; R. Dworkin 20II: 365); individual, psychological self-government (Christman I991; Hirschmann 1996; Carter 2019); and self-realization or flourishing (Skinner 2002; Bilgrami 2018). Indeed the term's most influential purveyor himself, Isaiah Berlin (1969a), seems to characterize positive freedom in mutually inconsistent ways within the space of only a few pages.

Why is this? Part of the explanation, though not all of it, is a persistent but often unacknowledged tendency to think of the distinction between positive and negative freedom as exhaustive. If the distinction is exhaustive, then positive freedom is any freedom that isn't negative, and vice versa. If negative freedom is narrowly defined, as it usually is (in terms, say, of noncoercion or physical nonprevention), then positive freedom must be widely defined. "Positive freedom" thus becomes a catch-all term for any rag-tag number of heterogeneous conceptions, united only in their rejection of the negative approach. After all, one thing that capabilities, collective self-determination, psychological self-government, and self-realization all have in common is the fact that none of them is equivalent to mere

Thank you to John Christman for his valuable advice and comments, as well as for inspiring me to embark on this project. Thank you also to Susan James for very helpful conversations and comments on the chapter. Finally, thank you to Robyn Blum, Kirstin Borgerson, Danielle Bromwich, Sophia Connell, Andrew Huddleston, Hallvard Lillehammer, Douglas MacKay, and Joseph Millum for their feedback on an earlier draft. 
noncoercion or physical nonprevention. If the positive/negative freedom distinction is exhaustive, this fact on its own suffices to qualify them (and many more besides) as "positive conceptions." For this reason, however, if "positive freedom" is to pick out its own distinct and internally coherent way of thinking about freedom, then the idea that the positive/negative distinction is exhaustive needs to be avoided.

Moreover, the root of this idea is a tendency to see the positive/negative distinction as a logical one concerning the underlying form of freedom claims. If the distinction is ultimately one of logical form - such as, for instance, between "freedom from" and "freedom to," or between analyses that take freedom to require the world to be a certain way and those that take freedom to require the world not to be a certain way - then it makes sense to expect it to be exhaustive. If "positive freedom" is to pick out a unified approach of its own, this way of thinking about the distinction must be avoided too. That is, even if there does turn out to be some purely formal distinction to be had here (a much-debated question: see e.g., MacCallum 1967; Christman 2005a; Nelson 2005; Elford 2013), this isn't the direction to look if we want a chance of viewing positive freedom as a coherent conception in its own right.

To do that, we need to treat "positive" and "negative" not as descriptions of logical forms but as names of intellectual traditions. Unlike logical forms, intellectual traditions are messy and historically contingent. Nevertheless, they're developed in response to intelligible philosophical problems and pressures, and manifest some degree of internal unity. Treating positive and negative freedom as intellectual traditions, therefore, allows each to be understood as its own coherent family of conceptions, and not simply as a repository of conceptions excluded by the other. The price of doing so, however, is treating the positive/negative distinction as gappy.

Recognizing the distinction's gappiness has another benefit, which is that it helps us to situate the ideas of positive and negative freedom in their proper cultural contexts. A philosophical tradition is more than just a set of positions located in conceptual space; it's a set of views developed over time by thinkers in intellectual contact with one another. This makes philosophical traditions inherently parochial in a way that philosophical positions, abstractly specified, aren't. I here take "positive freedom" to pick out one strand of what's generally (though inaccurately) termed as "Western" philosophy - that is, roughly, philosophical thought descended from Ancient Greece. In doing so, I take "positive freedom" and "negative freedom" to name ways of thinking that just happened to develop in 
particular times and places in response to local intellectual pressures, such that they're unlikely to exhaust the domain of conceptual possibilities for thinking about freedom. This opens space for thinking about other approaches too - such as the republican view, which (along with its feminist and black liberationist versions) grew in conversation with them, and views of freedom developed independently in other intellectual contexts, such as Confucian and Daoist views (Ni 2002; Jiang 20 I I, 20 I 2). In addition, it points to the fact that there may yet be important areas of conceptual space still to be explored.

In this chapter, I aim to bring the positive conception into better focus by tracing the positive tradition through some of its twists and turns, and considering in what ways it might qualify as a single tradition. Drawing on the lessons of this survey, I then suggest a way of thinking about the nature of positive freedom that is both principled and historically informed.

\section{I.I The Positive Tradition}

What, then, is the "positive" tradition? What gives it unity and coherence, and constitutes it as a single tradition? To answer these questions effectively, we'll need to do more than simply catalog different philosophers' accounts of freedom and point to their similarities and differences. To understand what really drives the positive tradition, we'll need to know not only what various philosophers took freedom to be but also, more deeply, why it mattered to them: what they took to be at stake in disagreements over the meaning of freedom. Only by understanding the underlying point of holding a positive account of freedom will we be able to fully understand what unifies it as a single tradition.

With this in mind, I suggest that we see the positive tradition as unified by unity itself: a commitment to the project of evaluative unification. More specifically, it's unified by a commitment to the view that freedom is necessarily coextensive with some or all of the values on the following list: (I) moral virtue, (2) reason and understanding, (3) well-being, and (4) oneness with God. Moreover, although "positive freedom" is now generally taken to be a political concept, its roots lie in a meta-ethical project that's concerned with the ultimate authority of moral norms. Accordingly, two principal philosophical motivations for seeking to establish this unification are to be found within the tradition - one meta-ethical, and one political - and we must distinguish carefully between them.

The central aim of the meta-ethical version of the evaluative unification project is to secure morality from skeptical challenge. It seeks to do this by 
showing that moral virtue is necessarily coextensive with, and therefore necessary for, the realization of (some or all of) the other values on the list. This project takes off from Plato and runs through the Stoics; Neoplatonism; much of Muslim, Jewish, and Christian philosophy in the medieval period; early modern rationalism; German idealism; and remains with us today in the form of neo-Kantian and neo-Hegelian orientations within contemporary moral philosophy.

The more familiar political version develops out of this. It's concerned with articulating a vision of the free society that might serve as a less individualistic alternative to the classical liberal ideal of a set of people bound by nothing other than their freely-entered-into contracts. It aims to show that freedom is necessarily coextensive with (at least) objective wellbeing and some form of ethical life, thereby supporting a view of the free society as one of socially embedded individuals reinforcing and constituting one another's freedom through mutual flourishing. Drawing on the rich legacy of the meta-ethical version, especially the work of G. W. F. Hegel and other politically oriented rationalists (such as Baruch Spinoza), this version of the project takes off in the wake of the Industrial Revolution and is developed primarily by socialists, antiImperialists, and left-liberals of the nineteenth and twentieth centuries.

Although the two versions have different philosophical aims, they're united in their commitment to evaluative unification. What's more, both draw on a shared pool of intellectual resources in order to establish that unification. Four basic argumentative strategies are particularly important, which I label as the rational order strategy, the reflective consciousness strategy, the recognition strategy, and the social nature strategy. In the next two sections, I sketch the historical trajectories of the two versions of the unification project, and I also outline these four basic strategies for securing the unification. Before embarking on this history, however, I make two preliminary points about its intended scope.

The first is that my topic here is the nature of freedom itself, i.e., what freedom is. We should recognize, however, that not everyone who's had something important and original to say about freedom has been concerned with its finer conceptual details, or has occupied themselves with advancing our strictly philosophical understanding of its fundamental nature. Many have focused instead on other pressing questions about freedom, such as how it's to be obtained, how it's to be preserved, or how it's curtailed in practice. This is true, for instance, of much Marxist theory: from Marx's immediate successors, Friedrich Engels and Karl Kautsky, to intellectual revolutionaries such as Rosa Luxemburg, 
Vladimir Lenin, Leon Trotsky, Mao Zedong, and Fidel Castro, to "Western Marxists" such as György Lukács, Karl Korsch, Antonio Gramsci, Antonio Negri, Max Horkheimer, Theodor Adorno, and Herbert Marcuse, to Marxist anticolonial theorists such as M. N. Roy, José Carlos Mariátegui, and C. L. R. James, theoretical attention has tended to focus more on the hows of freedom than on the what of freedom. That is, discussions of how exactly capitalism defeats human freedom, of how capitalist and state structures operate to shut off opportunities for freedom by myriad and subtle means (including ideological means), of how this can be meaningfully and successfully opposed in practice, of what a socialist society ought to look like - such discussions typically just take for granted something like Marx's conception of freedom as creative and cooperative self-realization (though see Cohen 1983 for a prominent exception). Such a conception forms part of the common political orientation that enables such theorists to debate other, more pressing questions within a shared conceptual framework. But these further questions aren't my topic here.

The second is this. It's that there's a difference between holding, say, a theory of self-realization, and holding a theory of freedom as self-realization. One can theorize self-realization in detail, and regard it as a concept of great importance, without identifying it with freedom. Hence one might have a theory of self-realization but define freedom negatively (as did J. S. Mill and Robson I98 I [I 824]: 296; MacGilvray 20 I I: I 59); or one might have a theory of self-realization and take no explicit view on the nature of freedom at all. One cannot be said, in these cases, to have a positive view of freedom. Of course, if we subscribe to the view that freedom is selfrealization (or collective self-determination, or social recognition, or any of the other things commonly identified with positive freedom), then, from our point of view, any theorist of these things is thereby a theorist of freedom - a freedom theorist de re, as it were. But there's no reason (yet) to ascribe to that theorist any thesis about freedom at all. The tradition of positive freedom, as I here understand it, isn't a tradition of theorizing these things; it's a tradition of theorizing freedom by identifying or connecting it with these things. My focus in what follows is, therefore, the development of explicit ideas about the concept of freedom itself.

\section{I.2 Evaluative Unification as a Meta-ethical Project}

Although freedom was by no means a central concept in classical Greek philosophy, our story nevertheless begins in the fourth century BCE with 
Plato's attempt to secure morality against skeptical challenges. Plato addresses a family of skeptical positions (voiced by Callicles in the Gorgias and Thrasymachus and Glaucon in the Republic), but the basic challenge can be characterized in terms of three central themes. The first is the idea that those who do good willingly are irrational: they're fools, duped to serve the interests of others at their own expense, whereas those who understand the true nature of the world see through morality's fog and pursue their own advantage with clear eyes. The second is the idea that morality requires us to act against our self-interest: morality commands us to be honorable and honest, and thus to forgo opportunities for selfadvancement. The third is the idea that morality is oppressive: both a constraint on our agency (as Glaucon puts it, "no man is just of his own free will, but only under compulsion" [Republic 36oc]), and an illegitimate mode of social control, a way for others to "subdue" us "into slavery" (Gorgias 484a).

In response, Plato mounts the strongest possible counterargument. Focusing on the charges of irrationality and disadvantage, he aims not only to reject these claims but to invert them. Thus, he argues that virtue stems not from a misunderstanding of the true nature of the world but from the greatest possible insight into the nature of reality (specifically, rational understanding of the Form of the Good). At the same time, he argues that justice isn't a restraint on one's ability to pursue one's interests but a constitutive condition of psychological well-being (since only a just soul can be internally well-ordered). So, morality, reason, and well-being necessarily coincide, and morality is thereby secured from skeptical challenge.

By contrast with reason and well-being, Plato has little to say about freedom, and he doesn't respond to the third strand of the skeptical challenge directly. Nevertheless, it's clear what he would need to argue were he to wish to extend the strategy: that moral virtue isn't oppressive, but liberating. Indeed, such an idea was already implicit in much of Plato's work (Stalley I998), and was increasingly brought to the surface by later theorists as they sought to shore up and extend his anti-skeptical arguments. In this way, it eventually became common to include freedom as an additional target of unification (as well as oneness with God, a theme of Plato's later works).

We see this most prominently with the Stoics. From the third century $\mathrm{BCE}$ to the second century CE, Stoic thinkers advanced exactly such a comprehensive version of the evaluative unification doctrine. Moreover, they developed a highly influential set of arguments in favor of it. 
According to Stoic doctrine, the world is a fully deterministic system providentially ordered by God in accordance with reason, such that everything occurs by both causal and rational necessity (Cooper 2003). As we become more rational, and achieve greater insight into the workings of the world, our rational purposes come into alignment with God's, and with the operation of the universe itself. Hence rationality entails oneness with God. Moreover, since everything that happens is rationally necessary, the truly rational person desires all and only what's actual, and is therefore guaranteed always to get what they want. Hence rationality entails wellbeing. What's more, insofar as we desire all and only what's actual, we can never be prevented or constrained from getting what we want. Hence rationality entails freedom. Finally, a rational order is one that treats all of its parts appropriately, and a rational person will be motivated accordingly. Hence reason entails morality. As the first-century Stoic Epictetus puts it, when the capacity for reason is rightly exercised "there is freedom, serenity, cheerfulness, constancy, and there is justice, too, and law, and self-control, and virtue in its entirety" (Discourses, $\mathrm{F}_{4}$ ).

Call this the rational order strategy. It relies on the key metaphysical premise that everything unfolds by rational necessity. Its basic idea, that reason, virtue, freedom, happiness, and oneness with God are necessarily bound together by an underlying rational order, and that this grounds the authority of morality, was the common intellectual currency for many centuries: important variations on the theme can be found, for instance, in the works of Ibn Sina (970-I037), Thomas Aquinas (I225-I274), and Gersonides (I 288-I344) among others. However, the view was also subject to increasing pressure, not from moral skepticism but from a rival view about the ultimate ground of moral authority. This was theological voluntarism: the view that the ultimate ground of morality is just God's arbitrary will.

Theological voluntarism has ancient roots; Plato himself famously saw fit to try to refute it in the Euthyphro, and it was debated forcefully throughout the medieval period. Yet the rise of Protestantism in the sixteenth and seventeenth centuries put it increasingly on the front foot. The view challenges every part of the evaluative unification doctrine. It holds that the ultimate justification of the moral law is rationally inscrutable, breaking the connection between virtue and reason. It makes God an external lawgiver located outside our moral community, breaking the connection between virtue and oneness with God. It denies that piety must be in our earthly interests, breaking the connection between virtue and well-being (that is, the constitutive connection: virtue and happiness 
remain instrumentally connected by means of divine reward and punishment). And it treats obedience to the moral law as a form of submission to God's arbitrary will, breaking the connection between virtue and freedom.

Some aspects of this voluntarist position can be found in the moral systems of philosophers as otherwise diverse as Hugo Grotius, Thomas Hobbes, René Descartes, Samuel von Pufendorf, and John Locke (Schneewind 1998). To some other philosophers of the sixteenth and seventeenth centuries, however, theological voluntarism was unacceptable in its entirety. If moral terms are definable only with reference to God's arbitrary will, then the idea of the moral goodness of God is emptied of content. What's more, if it's only God's brute power, and not His goodness, that supplies our reason for doing as He wishes, then God seems reduced to an amoral tyrant whose decrees we must subserviently obey. Thus Gottfried Leibniz, for instance, inveighed against those who took the view that God could "cause sins to be committed, simply at his will and pleasure," complaining that they "liken us to earthworms which men crush without heeding as they walk" (Theodicy, Preface).

Partly influenced by the Stoic revival of the late fifteenth century, several philosophers, therefore, attempted to beat back the threat of theological voluntarism by defending evaluative unification. Once again, they looked to the rational order strategy as a means of securing unification. Spinoza (I632-I677), Leibniz (I646-I7I6), and Christian Wolff (I679-1754) all developed speculative metaphysical systems aimed precisely at establishing the key premise of rational order, that the world unfolds by rational necessity. This enabled them to argue that the ultimate authority of moral rules lies not in God's arbitrary will but in reason itself; that virtue requires not self-abnegation but the full realization of one's own good; that reason and understanding bring us closer to God; and, most importantly for our purposes, that compliance with moral and rational principles is not a form of subjugation, but true freedom. As Spinoza puts it in his Ethics, therefore, "virtue itself, and the service of God" is "happiness itself, and the greatest freedom” (II, P.49, Schol.4a).

However, a persistent difficulty with the rational order strategy was its seeming commitment to causal determinism. If every event is rationally necessitated by prior events, then every event is predetermined. This idea, fundamental to the strategy, is one that many were unable to accept due to its apparent incompatibility with free will and moral responsibility. Indeed, Spinozism was widely condemned on these grounds, and Leibniz's disciple, Wolff, was banished from the University of Halle by 
theologians alarmed by the determinism seemingly inherent in Leibniz's Principle of Sufficient Reason.

It was in this context that Immanuel Kant (I724-I804) sought a new way of grounding the authority of moral imperatives. He, too, regarded the rational order strategy's commitment to determinism as morally unacceptable. Yet he also rejected theological voluntarism, holding that the ultimate ground of morality lies in our own capacity for reason and not in external commands. His task, therefore, was to find a way of grounding morality in human reason without presupposing a rational order. Part of his solution, famously sketched in his Groundwork of the Metaphysics of Morals ( 1785 ), was to try to uncover necessary conceptual connections between freedom, reason, and morality simply within the structure of reflective consciousness itself.

The basic idea is this. In deciding what to do, one could choose simply to act on the basis of some externally given principle, such as a natural inclination, an internalized norm, or a command. Yet any such externally given principle stands in need of further justification, and in failing to consider its further justification one abdicates one's powers of reason. Simultaneously, one forfeits one's freedom, since one allows oneself to be subject to an external principle. So, both freedom and reason demand that one step back from externally given principles of action and seek further justification for their authority; in this way, freedom and reason necessarily coincide in the search for self-given principles of action. Moreover, both necessarily coincide with morality too, since once one has stepped back from all contingently given principles, the only rational principles that remain are lawlike and universal in form, such that they must be binding on all rational beings. Hence freedom, reason, and morality necessarily coincide.

Call this the reflective consciousness strategy. It offers a pared-down version of the doctrine of evaluative unification, linking only morality, freedom, and reason. Its central idea, that both freedom and reason inhere in the very structure of reflective consciousness, is foundational to Kant's critical project. For many members of the influential generation of German philosophers who came up in the immediate aftermath of Kant, too, this served as the fundamental philosophical insight from which their systems were to be constructed (Henrich 2008). Moreover, some of these philosophers came also to accept the claim, initially associated with Friedrich Jacobi, that any fully coherent rationalist philosophy must be Spinozist, and so to seek a reconciliation of Spinoza with what they took to be the fundamental insights of Kant. This "Spinozism of freedom," 
a rational order derived from the structure of reflective consciousness, was to constitute a synthesis of the two strategies for evaluative unification.

This, in short, is the task that Hegel (I770-I 83 I) aimed to complete. In doing so, he also developed a sophisticated analysis of the inherently social dimensions of individual freedom that would prove highly influential. I note just two important features of his approach. First, part of what Hegel purports to find within the structure of reflective consciousness itself is the fact that free agents are rationally bound to protect and promote their own subjective capacity for freedom (Patten I 999). Yet, he holds, this subjective capacity is itself constitutively dependent on a certain form of life supported by particular social and political institutions. To protect and promote one's capacity for freedom, therefore, is necessarily to protect and promote the freedom-sustaining culture in which one finds oneself, and the social and political institutions that support it.

Second, Hegel brought to the fore a new argument designed to secure a version of the evaluative unification doctrine: the recognition strategy. The central idea is that in order to be a genuinely free or autonomous agent, and for your projects to have meaning and worth, your agency and autonomy must be acknowledged and recognized by others. Put differently: eternal solitude would eventually render all of your projects pointless, thereby undermining your capacity for autonomous agency. What's more, your agency and autonomy must be freely recognized by others. Coerced or brainwashed "recognition" is meaningless. In this way, the freedom of each is necessarily bound up with the freedom of all: free beings have reason to care about the freedom of others, since this is necessary for their lives to be worthwhile. Thus freedom, well-being (understood as selfrealization or meaningfulness), and ethical concern necessarily coincide.

For most of its history, the meta-ethical version of the evaluative unification project looked predominantly to versions of the rational order strategy as a way of securing the desired unification. Yet in the nineteenth and twentieth centuries, waning religious belief made it increasingly difficult to substantiate the key premise of rational order on which that strategy relies. As a result, philosophers came to focus more on alternative routes to evaluative unification, and both the reflective consciousness and recognition strategies became increasingly influential. Indeed the central question, for neo-Kantian and neo-Hegelian moral philosophers respectively, came to be whether sufficiently naturalized versions of these arguments could be extracted from the metaphysical systems in which they were originally embedded and be vindicated on their own terms. Attempts at affirmative answers to this question continue to this day: the meta-ethical version of 
the evaluative unification project has been, without doubt, one of the most stable and long-lasting research projects in human history.

\section{I.3 Evaluative Unification as a Political Project}

If evaluative unification could be established, however, its significance would not be restricted to meta-ethics alone. The original project was to defend morality by showing its necessary connections with reason, wellbeing, freedom, and oneness with God. But this same set of necessary connections, once in place, can be put to work in different ways. To take one set of examples: some early modern scientists sought to defend their work by arguing that by increasing our rational understanding of the world they were thereby increasing our virtue and freedom, and bringing us closer to God (Shapin 1996), and in the late seventeenth century Mary Astell (I666-I73I) argued (in her A Serious Proposal to the Ladies [1694]) in favor of the education of women partly on the grounds that to develop women's powers of reason is also necessarily to increase their virtue, freedom, well-being, and Godliness. Such arguments draw on the same inferential connections as the meta-ethical project but put them into reverse; that is, instead of seeking to defend virtue by appeal to its necessary connections with reason (and other values), they seek to defend reason by appeal to its necessary connections with virtue (and other values).

I turn now to another such redeployment of the unification doctrine. Its aim was to articulate an alternative to the rhetorically potent conception of market freedom that had emerged during the eighteenth century, and continued to develop and grow in political importance throughout the nineteenth and twentieth centuries. By "market freedom" I mean, roughly, the idea that open markets are essential to individual freedom (MacGilvray 20II). Prior to the Industrial Revolution, this was a predominantly republican idea, aimed at dismantling the monopoly power wielded by large landowners and guilds and eliminating the "servile dependency" they engendered. The eighteenth-century republican vision - as found, for instance, in the work of Adam Smith - was of a society of independent tradesmen, yeomen, and small-scale proprietors dealing with each other on equal terms, no longer vulnerable to the arbitrary whims of the local Lord or Baron. In the nineteenth century, however, industrialization and the vast economies of scale it permitted, radically changed the nature of economic production. As firms grew, new social hierarchies and new relations of domination and dependence arose within them. Market freedom ceased to be an unalloyed republican good (Anderson 2017). Indeed, 
republican ideas came to be influentially turned against the goal of unfettered markets, and a new "labor republican" movement, rooted in the working class, argued that propertyless wage laborers were subject to the domination of employers and therefore were unfree (Gourevitch 2013).

Partly for these reasons, the ideal of market freedom came to be defended by appeal to a thinner, negative conception of freedom. This conception, associated in this period most closely with Jeremy Bentham but descended ultimately from Hobbes, takes political freedom to consist primarily in "the silence of the laws," that is, in noninterference by the state or others in one's actions. It's controversial exactly to what extent the idea of negative freedom does in fact succeed in helping to support the ideal of market freedom (see, e.g., Cohen $20 \mathrm{IIb}$ ). However, what concerns us here isn't negative freedom in its strict philosophical form, but its rhetorical form: that (somewhat vague) ideal of noninterference typically invoked by politicians and polemicists in defense of small-state, laissez-faire capitalism. This is the idea to which positive theorists are best taken to be reacting.

Such a conception may be characterized, for current purposes, in terms of two key features. First, it's a conception of freedom as social noninterference: freedom is fundamentally a matter of other people getting out of your way. (What exactly it means for someone to be "in your way" in the relevant sense is a matter of some delicacy, the most common interpretations being physical prevention, coercion, and rights violation.) The second feature, which follows from the first, is a commitment to preference neutrality: a person's degree of freedom has nothing to do with the content of their preferences. Individuals may therefore be treated as black boxes from the point of view of freedom with no need to interrogate the nature or origin of their desires. Taken together, these features yield a view of freedom that appears at least prima facie conducive to the following, classically liberal picture of the free society: one of atomic individuals bound by nothing other than their own freely-entered-into contracts.

Many opposed this vision: from reformist, left-liberals to revolutionary socialists, this constituted a broad swathe of political opinion. Some, such as J. S. Mill, L. T. Hobhouse and Isaiah Berlin, accepted the negative account and opposed unrestricted market capitalism on the basis of values they took to be distinct from freedom, such as equality or selfdevelopment. However, others, such as Karl Marx (I818-1883), Thomas Hill Green (I 836-I882), John Dewey (I 859-I952), Hannah Arendt (1906-1975), and Simone de Beauvoir (1908-1986), sought to reject the negative conception. Instead, they argued that freedom is 
necessarily coextensive with active participation in some form of social and ethical life, and in doing so they drew on the rich legacy of the meta-ethical version of the evaluative unification project. Moreover, in addition to reworking the old strategies for establishing the unity of freedom with other values, some of them also turned to a newer one: the social nature strategy.

We see the continuing influence of the old strategies most clearly in the work of thinkers like Green. A key figure in the dissemination of German idealism within anglophone philosophy, Green deploys recognizably Kantian and Hegelian versions of the reflective consciousness and rational order strategies to demonstrate the necessary coincidence of freedom, reason, virtue, happiness, and oneness with (a somewhat naturalized) God. On the one hand, this evaluative unification offers him a traditional solution to the old problem of securing the moral order, here presented in Victorian guise as the problem of finding space for Christian conceptions of moral community within an increasingly scientifically disenchanted world. On the other hand, however, it also offers a solution to a newer problem, increasingly pressing for those of Green's political leanings: that of developing a philosophical critique of laissez-faire capitalism grounded in an alternative vision of liberalism (Simhony I993; Dimova-Cookson 2003; see also Simhony's and Dimova-Cookson's essays in this volume).

In particular, it enables him to define political freedom, not as noninterference, but as "the liberation of the powers of all men equally for contributions to a common good" (Green I986a: 200). This, in turn, allows him to move away from the wholehearted commitment to freedom of contract familiar from natural-rights-based forms of classical liberalism, and to mount a freedom-based argument for restrictions on trade and employment. Thus, for Green, one doesn't limit a person's freedom by preventing them from getting drunk, or taking an exploitative job: to the contrary, one keeps open a space in which they might come to attain freedom. Similarly, one doesn't limit a person's freedom by preventing them from selling alcohol, or exploiting others: one helps them to contribute to the common good, and so to realize their freedom. This is, for instance, the basis of the philosophical case that Green developed in favor of the legislative program of the reforming Liberal government of I 868 to $\mathrm{I} 874$.

However, not everyone was so amenable to the underlying idealist metaphysics that Green used to secure these conclusions. For less spiritually minded thinkers, the social nature strategy suggested a promising way forward. Drawn from Aristotelian ideas, its key premise is that we're 
naturally social beings, and that we can realize our natures only through certain forms of (at least minimally ethical) social relationships. Since to realize one's essential human nature is to flourish as a human being, this connects objective well-being with participation in social and ethical life. Moreover, inasmuch as freedom requires that we be determined to action not by alien forces but by our own essential natures, this individual and collective flourishing also necessarily coincides with individual freedom. Thus freedom is necessarily coextensive both with objective well-being and with participation in social and ethical life.

We find something like this line of thought, for instance, in Marx's early works (such as his Economic and Philosophic Manuscripts of I844). For Marx, our essential human nature - what he calls our "species being" consists in both doing and understanding ourselves as doing creative labor for the sake of the community. When we realize our essential human nature in this way, we flourish, and we experience our lives as meaningful and worthwhile. By contrast, when we're alienated from our own humanity, as Marx believes most people necessarily are under capitalism, we're reduced to a bestial existence, we experience our lives as meaningless (or we seek meaning in comforting illusions, like religion), and we're unfree (Wood I98 I; see also Michael Quante's essay, Chapter 2, in this volume). True freedom and human flourishing, therefore, necessarily coincide.

So too do freedom and ethical life. If we're inherently social beings, and if freedom consists in the realization of our human nature, then freedom requires that we act from an understanding of our proper role within society. It requires, for instance, that we work in concert to meet our shared needs, and that we exercise collective control over our jointly held productive powers. Someone who seeks to exploit or to dominate others is therefore necessarily unfree, since such a person is failing to act from consciousness of their true nature as an inherently social being. Thus true human emancipation, according to Marx, can be achieved only when each person "has become a species-being in his empirical life, his individual work and his individual relationships, only when man has recognized and organized his own forces as social forces so that social force is no longer separated from him" (Marx I975: 234).

Though elaborated in different ways, the idea that human beings are inherently social, such that our individual and collective flourishing is always ultimately in alignment, is one that's common to many different ethical traditions (including, among others, ancient Greek ethics, Ubuntu ethics, and Confucianism). However, not all such traditions explicitly identify this socially oriented form of individual flourishing with freedom 
or, indeed, treat freedom as a central moral value at all. However, as capitalism came to be exported and imposed around the world with increasing force throughout the nineteenth and twentieth centuries, many of its anti-imperial opponents turned to versions of the social nature thesis in order to articulate what they saw as the incompatibility between such traditional philosophical ideals of collective ethical life, on the one hand, and the ideal of market freedom, on the other. In some cases, as with Kwame Nkrumah (I909-I972) in Ghana and Julius Nyerere (I922-1999) in Tanzania, this involved connecting Marx's deployment of the social nature strategy with existing versions of the social nature thesis; in other cases, as with Mahatma Gandhi (1869-1948) in India, local versions of the thesis were harnessed in service of anti-imperialist ends without any general commitment to Marxism (Bilgrami 20I4).

Some non-Marxist liberals, too, looked to the social nature strategy as a promising basis for rejecting unfettered market capitalism. Dewey, for instance, took the negative conception of freedom to be the lynchpin of a dangerously atomized, overly individualistic form of liberalism that he wished to reject. Drawing from Hegel, he argued that human beings are necessarily constituted by their cultures and their social institutions, and that this inherent sociality renders mere noninterference a questionable ideal. Instead, a true concern for freedom requires that we look to the nature of our institutions, and that we aim to create and maintain a culture that permits the full development of individual potential. Thus liberty is "that secure release and fulfilment of personal potentialities which take place only in rich and manifold association with others" (Dewy I $927 \mathrm{~b}$ : I 50), and it's possible only within a substantively democratic culture in which people exercise collective deliberative control over the full range of social and economic institutions by which they're constituted.

Similarly, Beauvoir deployed a version of the social nature strategy with Hegelian elements, though hers is a distinctively existentialist rendering of that idea. For her, as for other existentialists, human beings are fundamentally, ontologically free; this is something we can either deny, by living alienated lives bound by external rules and norms, or realize, by living authentically and taking ultimate responsibility for our choices. But only in the latter case do we achieve a second, higher form of freedom authenticity - and only then are our lives and projects truly meaningful. In this sense, failure to realize one's own freedom as authenticity is selfdestructive; it's also irrational, inasmuch as freely pursuing unfreedom can be taken to involve a kind of practical contradiction. These lines of thought connect freedom, flourishing, and reason. Yet a common criticism 
of existentialism as developed in the mid-twentieth century was that its strict denial of the bindingness of external values and norms committed it to a form of moral nihilism. Beauvoir did more than anyone else to rebut this charge (primarily in her The Ethics of Ambiguity [1976]), and she did so in a way that also enabled her to reject socially atomistic forms of liberalism in favor of more democratic and egalitarian social and political institutions.

Beauvoir seeks a middle path between a conception of human beings as pure, free, reflective consciousnesses and one of them as materially embodied and causally determined. Hence consciousness is fundamentally free humanity is freedom - but it's also, essentially, constrained by the world around it: the natural world, and the world as shaped by our past and current actions, including the social meanings with which we've imbued it (Morgan 2008). This tension between our "transcendence" and "immanence" is, for her, the fundamental ambiguity at the heart of the human condition. It means that our freedom, although primary, is vulnerable to the world, and especially to the social world. Insofar as we value our own freedom, then, we must value the freedom of others, and we must act together to protect and promote our freedom over time by developing democratic institutions capable of respecting both our individual freedom and our social embeddedness (Pettersen 2015). Thus freedom, flourishing, reason, and morality all necessarily coincide in the fully authentic life: this is an existentialist rendering of the classic doctrine of evaluative unification.

\section{I.4 Positive Freedom: Its Shape}

I've argued that "positive freedom" names a particular intellectual tradition. This tradition, I've suggested, is unified by a concern with evaluative unification, but disunified with respect to the overall programmatic aims of that unification. Whereas some positive theorists have sought unification in order to supply an ultimate ground for moral authority, others have done so in order to support a non-individualistic conception of the free society, and still others have done so for both purposes at once. Nevertheless, what constitutes the positive tradition as a unified whole is its endorsement of conceptions of freedom that permit the unification of freedom with some or all of reason, virtue, well-being, and oneness with God. A positive conception of freedom, therefore, may be profitably characterized as any conception of freedom primarily designed to facilitate such a unification. 
This approach offers a more promising way of making sense of the idea of positive freedom than one that seeks to analyze it in terms of its underlying conceptual form. Positive accounts needn't share a single underlying conceptual form. For instance, it's often been pointed out that a standard negative account, on which freedom is construed as an absence of external constraints, can be transformed into a positive one simply by expanding what's meant by "constraints" (MacCallum I967; Nelson 2005). If "constraints" are taken to include internal constraints, and more to the point - if irrational, immoral, or self-destructive motivations are taken to be necessarily constraining, then we'll have arrived at what is, in effect, a positive view. Some have taken this to show that there's no deep distinction to be drawn between positive and negative accounts. Yet what makes a view positive isn't its attitude towards the idea of constraint, but its taking freedom to be necessarily coextensive with rationality, virtue, well-being, or oneness with God - a doctrine that's compatible with a variety of different positions regarding the nature of constraints.

Epictetus, for example, starts from a definition of freedom as the absence of all possible constraints to the satisfaction of actual desires (Discourses, D4.I). As a view of the relationship between freedom and constraint, that's a difficult position to categorize. It shares with modern republican accounts the idea, rejected by negative ones, that merely possible constraints are sufficient to compromise freedom; but it departs from both in focusing only on possible constraints to actual desires. Nevertheless, it becomes a positive account when combined with the Stoic version of the rational order doctrine to yield the view that freedom, so defined, is necessarily coextensive with reason, virtue, well-being, and oneness with God.

By contrast, Spinoza defines freedom as that "which exists from the necessity of its nature alone, and is determined to act by itself alone," and unfreedom as that which is "determined by another to exist and produce an effect in a determinate way" (Ethics I, def. VII). This definition doesn't depend on any meaningful conception of constraint at all; instead, it focuses on the causes of one's activity. What justifies us in ascribing a positive account of freedom to Spinoza isn't any purely logical feature of this definition, but the fact that he deploys it in concert with a broader metaphysical system designed to secure evaluative unification. Positive freedom isn't positive by virtue of having a certain canonical underlying logical form; it's positive by virtue of being designed to facilitate such a unification. 
Nevertheless, positive accounts do typically share certain general features, and this way of characterizing them with reference to their historical point allows for a satisfying and unified explanation of them. Four such features are particularly important. They are, first, the idea that freedom has specific content; second, the idea that freedom is an exercise concept; third, a focus on inner freedom; and, fourth, a tendency towards split views of the self. Taken together, these give the general shape of any traditional positive approach, and all four can be explained in terms of the imperatives of evaluative unification.

I start with specific content. On a negative approach, removing constraints frees people regardless of what they choose to do with that freedom. Republican accounts, too, typically take freedom to be preference-neutral, insofar as they tend not to place principled limits on what undominated people might choose to do. By contrast, positive accounts traditionally require that free people act in certain ways, or on the basis of certain motivations. According to Kant, for instance, you're autonomous only insofar as you're acting from pure principles of practical reason; according to Green, similarly, you're free only insofar as you're acting out of concern for the common good. Different positive accounts may set broader or narrower prescriptions regarding this specific content. But it's a common commitment of traditional positive accounts that those who act, say, immorally, or irrationally, or self-destructively, are thereby unfree. This follows trivially from evaluative unification.

Moreover, this idea that freedom has specific content entails that merely having a range of options is insufficient for freedom. In Charles Taylor's (I 979) terms, therefore, positive freedom is an "exercise" concept. If freedom requires you to choose or act in certain ways - that is, if freedom has specific content - then options aren't enough: you have to choose or act in the specified ways. Thus Marx, for instance, doesn't take freedom merely to require that one have the option of engaging in unalienated labor. One must actually do so, and someone who "chooses" to engage in alienated labor instead isn't free. In this sense, positive accounts treat freedom as a particular mode of agency (Christman 2005a). This also follows from evaluative unification. That's because rationality, virtue, and well-being are all exercise concepts: you don't qualify as rational or virtuous or flourishing just on account of having the options of acting in rational or virtuous or flourishing ways - you actually have to exercise those options. And if freedom is to be necessarily coextensive with one or more of these exercise concepts, then it must be treated as an exercise concept too. 
What's more, if freedom is an exercise concept - a particular mode of agency - then it must also be, at least in part, an internal or psychological matter. Unlike negative and republican accounts, which traditionally focus mainly on external enemies of freedom, positive accounts are centrally concerned with questions of motivation and consciousness. Thus the Roman Stoics famously held that even someone with maximal external freedom, such as an Emperor, could nevertheless lack true freedom by having a slavish mentality (and that, contrariwise, even a slave could be truly free). Other positive conceptions, such as Kantian moral autonomy, are realizable in the absence of external freedom too. Moreover, this focus on the psychological aspects of freedom is also a direct upshot of evaluative unification. Rationality and virtue are internal properties, at least in part; throughout much of the tradition well-being, too, was conceived as something wholly internal, such as ataraxia or calmness of mind. Thus, if freedom is necessarily coextensive with rationality, virtue, and wellbeing, and if rationality, virtue, and well-being are internal properties, then freedom must also be an internal property.

Of course, not all positive theorists do take freedom to be a wholly internal matter. Yet this, too, can be explained with reference to the imperatives of evaluative unification. For not all positive theorists take rationality, virtue, and well-being to be wholly internal properties either. Instead, some argue that their full realization in fact requires participation in certain kinds of social relationships. Thus Hegel, for instance, sees reason itself as subject to historical development, such that certain modes of practical rationality are available only within particular historical and cultural contexts. True rationality is therefore an inherently social, and so partly "external," achievement. More obviously, proponents of the social nature strategy take well-being to be a partly "external" achievement, such that one can truly flourish only in the right kinds of relationship with others. Despite a common concern with the internal aspects of freedom, then, positive conceptions are often intimately concerned with its external aspects too.

Finally, this general concern with internal freedom brings with it a standing tendency towards split views of the self. The connection is this. Everyone is susceptible to irrational, immoral, and self-destructive ideas and dispositions. If freedom requires rationality, virtue, and flourishing, then such wayward inner forces are obstacles to freedom. Insofar as you're subject to them, that is, you're unfree; freedom requires you to rise above them and to liberate yourself from their grip. This holds regardless of their phenomenal aspects; it simply follows from evaluative unification that 
irrational or immoral or self-destructive internal forces are blockages on the path to true freedom. From here it's then a short step (though not, strictly, a necessary one [Garnett 2017]) to the idea that these motivations are internal constraints and so external or alien to one's true self. This yields a view of the self as always fundamentally split between these alien forces, on the one hand, and the "true" self of reason or virtue or flourishing, on the other (Berlin I969).

Variations on this "split self" theme occur throughout the tradition. However, the form it takes differs greatly depending on whether the task of overcoming self-alienation is conceived primarily in individual or in social terms. For the Stoics, for example, liberation is primarily a matter of learning to control your own irrational impulses: in Plato's famous metaphor from the Phaedrus, you must tame the unruly horse of irrational desire and prevent it from dragging your chariot off course. For Hegel and Marx, by contrast, there are limits to what any individual can achieve in this regard, and freedom instead requires the creation and maintenance of non-alienating societies. For Marx, for instance, people can't fully realize themselves as species beings while treating others instrumentally as means to profit, but capitalism's structure of material incentives works specifically to force people to do this. Only by overcoming the alienating features of our social system, therefore, can we overcome the alienation within ourselves.

All four common features of traditional positive accounts can be explained, therefore, in terms of the historical point of this approach in securing evaluative unification. I submit that understanding the tradition of positive freedom in terms of its commitment to the project of evaluative unification, as this chapter has argued we should, allows for a clear view of its general shape, its strengths, and its weaknesses and, most importantly, its further theoretical possibilities. 